\title{
MODEL OF ISLAMIC MONETARY OPERATION FOR LIQUIDITY MANAGEMENT IN ISLAMIC BANKING Case of Indonesia 2000-2009
}

\section{Rifki Ismal}

Faculty of Economics

University of Indonesia

The paper attempts to construct the model of islamic monetary operation for liquidity management in islamic banking. Particularly, the model investigates variables that determine the role of the central bank in managing liquidity. Firstly, it explores the related conventional models and chooses one to find general variables involved in monetary operations for managing liquidity. Secondly, it formulates the islamic model after considering the islamic monetary operation principles, characteristics of both islamic monetary instruments and Indonesian islamic banking industry. Specifically, it models Bank Indonesia's islamic monetary instrument called Bank Indonesia Sharia Certificate (SBIS). Thirdly, the model points out that the volume of SBIS is influenced by reserves requirement, currency in circulation, and prior auctions of SBIS. It means that the application of islamic OMO is not significantly different from monetary instrument in conventional OMO. Therefore, the paper suggests the issuance of islamic investment monetary instruments to implement the ideal islamic monetary instrument and OMO.

Keywords: Bank Indonesia Sharia Certificate (SBIS); currency in circulation; islamic banking; open market operation (OMO); reserves requiremen; Sharia 
Gadjah Mada International Journal of Business, May-August 2009, Vol. 11, No. 2

\section{Background}

The Indonesian islamic banking industry is very prospective, shown by its robust performance in the last two decades. Nevertheless, the changing economic and business environments have required islamic banks to have a proper liquidity management to optimally utilize the depositors' funds and avoid liquidity risk problem. Theoretically, liquidity risk problems might prevail because of internal failures to manage the funds, or due to unfavorable economic conditions causing unpredictable liquidity withdrawals by depositors.

In order to manage liquidity, there are at least two options: (1) building a robust internal liquidity management in a bank to balance liquidity on asset and liability sides and (2) having an optimal role of central bank in managing liquidity of the banking industry. In fact, the Indonesian islamic banks have had sound internal liquidity management to balance the liquidity on the asset and liability sides (Ismal 2009: 14). Nonetheless, the role of central bank in conducting the islamic open market operation (OMO) to manage liquidity in the industry and prevent liquidity pressures has yet to be optimized. Besides the minimum volume of auction compared to conventional banks and the limited participation of islamic banks in islamic OMO, there are other factors that need to be investigated to improve the performance and role of islamic monetary operation.
Actually, the islamic OMO in Indonesia uses Bank Indonesia Sharia Certificate(SBIS) as the monetary tool to absorb or inject liquidity to the industry. As such, this paper attempts to investigate factors that determine the volume of SBIS to improve the islamic OMO and support the management of liquidity in islamic banking industry. Indeed, the assessment of the paper would benefit the banking regulator (central bank), islamic banks, depositors, and the islamic banking literature related to islamic monetary policy and operation.

The next sections of this paper examine some conventional models of the central bank monetary operation for liquidity management. Amongst all models, Bindseil's (2000) model in his paper entitled "Central Bank Liquidity Management: Theory and Euro Area Practice" is utilized since the model is concentrated on the demand and supply for liquidity and the role of central bank in managing liquidity in the banking industry. Moreover, the variables in the model and the monetary operation formula have many similarities to the Indonesian case. Referring to Bindseil's (2000) model, this paper constructs the model of islamic monetary operation and identifies variables that influence the Indonesian islamic OMO. Finally, based on the findings of the model, one important suggestion is to create the islamic investment monetary instrument to improve the current islamic OMO. 
Ismal-Model of Islamic Monetary Operation for Liquidity Management in Islamic Banking

\section{Conventional Models of Monetary Operations for Liquidity Management}

The conventional models of monetary operations address some important points with respect to monetary operations for liquidity management. For instance, Mills (2005:4) suggests in his model that: (1) fiat money is necessary as a means of payment; (2) there is a need for banks to acquire liquidity for making payments; and (3) liquidity is necessary to repay debts. Freixas and Rochet (1999: 161) emphasize the roles of central bank in supplying liquidity in the form of auctions of reserves and short-term advanced liquidity. They quote two different views of monetary operations: (1) the money view which stresses the importance of bank's liability side and (2) the credit view which insists on the importance of the bank's asset side (credit).

Meanwhile, Walsh (2003:323) explains the existence of imperfect information in credit market, adverse selection, moral hazard, monitoring costs, and agency costs as factors influencing bank loans and central bank monetary operations. Finally, with respect to the monetary operation to manage liquidity in banking industry, Bindseil (2000:3) concentrates on the demand and supply for liquidity and the role of central bank in managing liquidity in the banking industry. Because of the focus of the model, the monetary operations, and the similarities of variables with the Indonesian case, Bindseil's (2000) model is used in this paper to find variables involved in the monetary operations to manage liquidity in the banking industry.

First of all, Bindseil identifies three suppliers of liquidity for the banks: (1) open market operation (OMO); (2) standing facilities, and (3) autonomous factors. These three suppliers are formulated as:

$$
\begin{aligned}
\mathrm{C}_{\mathrm{t}}= & \mathrm{m}_{\mathrm{t}}+\operatorname{ltro}_{\mathrm{t}}+\left(\mathrm{l}_{\mathrm{t}}-\mathrm{d}_{\mathrm{t}}\right)-\left(\mathrm{bn}_{\mathrm{t}}+\mathrm{ggl}_{\mathrm{t}}\right. \\
& \left.+\mathrm{oaf}_{\mathrm{t}}-\mathrm{nf}_{\mathrm{t}}-\mathrm{fx}_{\mathrm{t}}\right) \ldots \ldots \ldots \ldots \ldots(1)
\end{aligned}
$$

where,

$\mathrm{C}_{\mathrm{t}}$ = the supply function of liquidity for banks with the influence of central bank monetary operations;

$\mathrm{m}_{\mathrm{t}}$ = the main refinancing operations;

ltro $_{t}=$ the longer term refinancing operations;

$\mathrm{l}_{\mathrm{t}} \quad=$ the marginal lending facilities; $d_{t}$ is the deposit facilities;

$\mathrm{bn}_{\mathrm{t}}=$ banknotes in circulation;

$\operatorname{ggl}_{t}=$ the liabilities to general government;

oaf $_{t}=$ the other autonomous factors;

$\mathrm{nf}_{\mathrm{t}}=$ net float, and

$\mathrm{fx}_{\mathrm{t}}=$ foreign exchange asset.

OMO is represented in the formula as $\left(\mathrm{m}_{\mathrm{t}}+\mathrm{ltro}_{\mathrm{t}}\right)$ while the usage of standing facilities by banks is in the first bracket, and the autonomous factors are in the second bracket.

In fact, the liquidity creation in the economy comes firstly from the central bank open market operation, which is a reverse liquidity - supply- 
Gadjah Mada International Journal of Business, May-August 2009, Vol. 11, No. 2

ing operations. In contrast to OMO, the standing facilities are an initiative of the counterparties to the central bank. Marginal lending facilities are liquidity provided by the central bank for banks that have liquidity shortages while deposit facilities are provided by the central bank for banks to place their end-of-the-day surplus liquidity. The autonomous factors are the central bank's activities which affect the liquidity out of its liquidity management and counterparties' requests (Bindseil 2000: 2).

Next, the demand function for liquidity, which is the central bank's liquidity contraction, consists of two main elements: (1) reserves requirement (v); and (2) excess reserves (x). Hence, a complete model capturing the demand and supply for liquidity is formulated by Bindseil as follows:

$$
\begin{aligned}
m_{t}= & \operatorname{ltro}_{t}+\left(l_{t}-d_{t}\right)-\left(b n_{t}+g g l_{t}\right. \\
& \left.+o a f_{t}-n f_{t}-f x_{t}\right)=v+x \ldots .
\end{aligned}
$$

Furthermore, the standing facilities have a cost variable $\left(\mathrm{i}_{\mathrm{ml}}\right)$ which has to be borne by the borrowing banks. The rate of $i_{m l}$ commonly refers to the market rate (i) and the rate of deposit facilities $\left(i_{d}\right)$ of the funds deposited in the central bank. Hence, the rate of central bank lending and the rate of deposits have the following functional forms (Bindseil 2000:7):

$$
\begin{array}{ll}
\forall \mathrm{i}_{\mathrm{ml}}: \mathrm{L}(\mathrm{i})=0 & \forall \mathrm{i}>\mathrm{i}_{\mathrm{d}}: \mathrm{D}(\mathrm{i})=0 \\
\forall \mathrm{i}>\mathrm{i}_{\mathrm{ml}}: \mathrm{L}(\mathrm{i})=\infty & \forall \mathrm{i}<\mathrm{i}_{\mathrm{d}}: \mathrm{D}(\mathrm{i})=\infty \\
\mathrm{i}=\mathrm{i}_{\mathrm{ml}}: \mathrm{L}(\mathrm{i})=\mathrm{A}-\mathrm{M} & \mathrm{i}=\mathrm{i}_{\mathrm{d}}: \mathrm{D}(\mathrm{i})=\mathrm{M}-\mathrm{A}
\end{array}
$$

$L$ (i) stands for the total amount of standing facilities borrowed by banks while $D(i)$ is the total amount of banks' deposits in the central bank. $A$ is the accumulation of banks' borrowings over certain periods, and $M$ is the accumulation of banks' deposits in the central bank. In practice, $i_{m l}$ and $i_{d}$ also influence the overnight rate ( $\left.i_{t}\right)$ in the money market as formulated below (Bindseil 2000:8):

$$
\begin{array}{r}
\mathrm{i}_{\mathrm{t}}=\mathrm{E}_{\mathrm{t}}^{\mathrm{b}}\left(\mathrm{i}_{\mathrm{m}}\right)\left[\int_{-\infty}^{\mathrm{v}} f_{\mathrm{t}}^{\mathrm{b}}(\mathrm{M}-\mathrm{A}) \mathrm{d}(\mathrm{M}-\mathrm{A})\right]+ \\
\mathrm{E}_{\mathrm{t}}^{\mathrm{b}}\left(\mathrm{i}_{\mathrm{d}}\right)\left[\int_{\mathrm{v}}^{\infty} f^{\mathrm{b}}(\mathrm{M}-\mathrm{A}) \mathrm{d}(\mathrm{M}-\mathrm{A})\right]
\end{array}
$$

The first [.] is the period of liquidity shortages in the money market whereas the second [.] is the period of excess liquidity in the money market. As such, the overnight rate corresponds to the weighted expected rate of $i_{m l}$ and $i_{d}$ and the estimated amount of nonborrowed funds or $M-A$. 
Ismal-Model of Islamic Monetary Operation for Liquidity Management in Islamic Banking

With regard to monetary operations, in particular to control and manage liquidity in the banking industry, the central bank operates OMO with the amount of allotment as a signal to market players. For the banks, such amount contains two unobserved stochastic variables: (1) the estimated amount of bank reserves that the central bank is willing to control and (2) the estimated autonomous factors. Both of them are linked in a linear equation (Bindseil 2000: 10), which is:

$$
\mathrm{m}=\mathrm{v}+\varepsilon-\gamma
$$

where $\mathrm{m}$ acts as the amount of allotment of OMO;

$\mathrm{v}=$ total amount of bank reserves that the central bank is willing to manage;

$\varepsilon=$ represents a forecast of autonomous factors; and

$\gamma=$ marginal values of reserves at the end of the period.

\section{Central Bank Model of Islamic Monetary Operations for Liquidity Management}

\section{Islamic Purposes of Monetary} Operations and Characteristics of the Indonesian Islamic Banking Industry

In principle, the purposes of islamic monetary operations in Islam are to (Ahmed 1983: 5-20): (1) im- prove economic well-being with full employment and an optimum rate of economic growth; (2) develop socioeconomic justice and equalize the distribution of income; and (3) stabilize the value of money. Moreover, Chapra (1985) highlights some characteristics of islamic monetary instruments, such as: (1) targeting high powered money such as base money or currency in circulation; (2) in accordance with the usage of reserves requirement; (3) in cooperation with fiscal policy for liquidity contraction/expansion; and (4) being engaged in real sector activities, which are free from prohibited activities (interest, uncertainty, etc.). One important point here is that the applications of islamic monetary instruments are different from those in the conventional banks in the sense that they link liquidity in the financial sector to the real sector.

Besides the islamic purposes and general characteristics of islamic monetary instruments, the Indonesian islamic banking industry has some specific characteristics to be accommodated in the construction of the islamic model:

1. Indonesia adopts dual banking systems with islamic banking holding around two per cent market share ${ }^{1}$ of the total banking industry. As such, the general impact of the monetary operations and economic conditions typically goes to the conventional banks followed by islamic banks.

\footnotetext{
${ }^{1}$ Until the end of 2008.
} 
Gadjah Mada International Journal of Business, May-August 2009, Vol. 11, No. 2

2. The movement of macroeconomic variables mostly applies to the conventional banks such as changes in the volume of banknotes (currency) in circulation, liabilities to general government, autonomous factors, and foreign exchange assets. The islamic model assumes that these variables do not specifically and directly persuade islamic banks. Thus, variables of oaf, $n f_{t}$, and $f x_{t}$ are not considered in the model.

3. As in the Bindseil's model, Indonesian case has an islamic OMO with SBIS as the islamic monetary instrument. There is also government sukuk(Government Islamic Securities or SBSN) launched in early 2008. Unfortunately, the Sukuk market is still in its infancy; therefore, SBSN and corporate sukuk do not take part in the islamic model.

4. SBIS uses Joalah contract ${ }^{2}$ and stands as the ultimate islamic monetary instrument for the central bank besides reserves requirement. Changing/adjusting the allotment of SBIS is easier and more flexible than changing the central bank's regulation on reserves requirement. In this case, the central bank pays fees to the banks that deposit their money in SBIS certificates, and the fee rate refers to SBI rate. ${ }^{3}$
5. The same as European model in Bindseil, Bank Indonesia has standing facilities (FF) for islamic banks, namely Intraday Liquidity Facility (FLI) ${ }^{4}$ and Short-term Financing Facility for Sharia Banks (FPJP). ${ }^{5}$ FLI can be used by islamic banks which are faced with liquidity shortages on a daily basis (one day limit) while FPJP is offered to help islamic banks which still have liquidity shortages beyond one day up to 90 days ahead. For this, Bank Indonesia charges fees for the use of FLI or/and FPJP.

6. Reserves requirement is stipulated to be five per cent of the total rupiah deposits and three per cent of the total foreign exchange deposits. In addition to five per cent reserves requirement, the latest Bank Indonesia's banking regulation ${ }^{6}$ stipulates extra reserves requirement to any islamic bank which has Financing to Deposit Ratio (FDR) below 80 per cent. Fortunately, the total industry FDR has been always standing above 100 per cent since 2001, and there is an insignificant portion of foreign deposits (Ismal 2009: 2). As such, the islamic model only considers the five per cent rupiah reserves requirement and ignores both the three per cent foreign

\footnotetext{
${ }^{2}$ It is a service based contract where the participants will receive fee because of their services to help the monetary operation.

${ }^{3}$ Bank Indonesia Regulation Number 10/11/PBI/2008, year 2008.

${ }^{4}$ Bank Indonesia Regulation Number 7/24/2005, year 2005.

${ }^{5}$ Bank Indonesia Regulation Number 7/23/2005, year 2005.

${ }^{6}$ Bank Indonesia Regulation Number 6/21/2006, year 2006.
} 
Ismal-Model of Islamic Monetary Operation for Liquidity Management in Islamic Banking

exchange reserves and extra reserves requirement.

7. Bank Indonesia does not pay any remuneration for the reserves requirement. ${ }^{7}$ Therefore, variable $i_{d}$ is not applicable to the islamic banking model. Furthermore, as commonly known as the main feature of islamic banking principles, any kind of interest is prohibited in Islam such that interest of central bank lending facilities $\left(\mathrm{i}_{\mathrm{ml}}\right)$ and interbank money market rate (i) are not part of the islamic model.

\section{Central Bank Model of Islamic Monetary Operation}

The central bank model of islamic monetary operation for liquidity management is formulated by referring to the variables in conventional (Bindseil's) model. Nevertheless, the model considers the purposes of islamic monetary operation, the general characteristics of islamic monetary instruments, and the special characteristics of Indonesian islamic banking industry. The model is written as follows:

$\mathrm{SBIS}_{\mathrm{t}}+\left(\mathrm{FF}_{\mathrm{t}}-\mathrm{D}_{\mathrm{t}}\right)-\left(\mathrm{CR}_{\mathrm{t}}+\mathrm{COg}_{\mathrm{t}}\right)=\mathrm{v}_{\mathrm{t}}$

SBIS operates through an islamic OMO which can absorb/inject liquidity to the industry. $F F_{t}$ the central bank's emergency liquidity provision to help islamic banks which are faced with liquidity needs. Both of these instru- ments usually cause liquidity expansion in the economy. $D_{t}$ is the total islamic bank deposits. $C R_{t}$ is the currency in circulation, $\mathrm{COg}_{t}$ is the government accounts in the central bank, and $\left(v_{t}\right)$ is the bank reserves requirement in Bank Indonesia. Through OMO, $D_{t}$ and $C R_{t}$ impose liquidity contractions and through Bank Indonesia's and government's regulations, $v_{t}$ and $\mathrm{COg}_{t}$ also impose the same impact.

Considering the role of every variable in equation (6), the demand and supply for liquidity in islamic banking industry can be estimated, and the central bank might use its islamic monetary instruments to balance any liquidity mismatch. First of all, in its maturity date, the principal of SBIS will be repaid to the islamic banks including the service fees. These are the liquidity expansions, and the fees themselves are the additional (new) liquidity to the existing liquidity. The total of these two liquidity expansions is represented by the following formula:

$$
\begin{aligned}
\text { SBIS }_{\mathrm{t}} & =\int_{0}^{360-\mathrm{T}} \operatorname{SBIS}_{\mathrm{t}}\left(\frac{\mathrm{T}}{360}\right) \mathrm{r}_{\mathrm{sbis}} \mathrm{d}\left(\mathrm{r}_{\mathrm{sbis}}\right)+ \\
& \int_{0}^{360-\mathrm{T}} \operatorname{SBIS}_{\mathrm{t}}\left(\frac{\mathrm{T}}{360}\right) \mathrm{d}(\mathrm{SBIS})
\end{aligned}
$$

where $T$ as tenor of SBIS and $r_{\text {sbis }}$ as fees of SBIS. The first integration is the total amount of SBIS fees paid to

\footnotetext{
${ }^{7}$ Bank Indonesia Regulation number 6/21/2006, year 2006.
} 
islamic banks while the second integration is the total amount of matured SBIS.

Besides islamic OMO, when requested, the central bank may provide FF (FLI or/and FPJP) as the shortterm emergency funds for islamic banks. The payment of FF gives another expansionary effect but the repayment of it, as there is a charge of using $F F$, is the liquidity contractions. The total amount of liquidity expansions due to the operation of FF (FLI + FPJP) is modelled as:

$$
\begin{aligned}
\mathrm{FF}_{\mathrm{t}}= & \left.\int_{0}^{1} F \mathrm{FL}_{\mathrm{t}} \mathrm{d}(\mathrm{FLI})_{\mathrm{t}}\right)+ \\
& \int_{2}^{90-\mathrm{t}} \mathrm{FPJP} \mathrm{d}_{\mathrm{t}}(\mathrm{FPJP})
\end{aligned}
$$

The first integration is the total amount of FLI on overnight basis, and the second integration is the total amount of FPJP from day 2 to less than 90 days ahead. However, the total payment of fees from islamic banks because of using FF (liquidity contractions) is:

$$
\begin{aligned}
\mathrm{FF}_{\mathrm{t}}= & \int_{0}^{1} \mathrm{FLI}_{\mathrm{t}}\left[\mathrm{r}_{\mathrm{p}} \gamma\left(\frac{\mathrm{t}}{\mathrm{T}}\right)\left(\frac{1}{360}\right)\right] \mathrm{d}(\gamma)+ \\
& \int_{2}^{90-\mathrm{t}} \mathrm{FPJP}_{\mathrm{t}}\left[\mathrm{r}_{\mathrm{p}} \gamma\left(\frac{\mathrm{t}}{360}\right)\right] \mathrm{d}(\gamma) \ldots . .(9)
\end{aligned}
$$

with $t$ stands for how long (minutes/ hours/days) an islamic bank uses FLI/ FPJP; $T$ is the total tenor of FLI/FPJP; $r_{p}$ represents islamic money market rate and $\gamma$ is profit sharing portion (fees) paid to the central bank.

The positions of the other two elements, total islamic banking deposits (D) and currency in circulation(CR), depend on the target auction of the central bank's monetary operation (OMO). Meanwhile, liquidity from liabilities to government (COg) and reserves requirement (v) automatically goes to Bank Indonesia without any monetary operations needed.

Finally, using islamic OMO, the central bank can balance the liquidity of the industry through an SBIS auction. As such, the comprehensive Central Bank Model of islamic of monetary operation for liquidity management as a function of allotment is formulated as follows:

$$
\begin{aligned}
\text { SBIS }_{t}= & \int_{0}^{t}\left(C_{t}+D_{t}-v_{t}-C O g_{t}\right) \\
& d(C R, D, v, C O g) \\
& \left.-\int_{0}^{1} F_{t} I_{t} r_{p} \gamma\left(\frac{t}{T}\right)\left(\frac{1}{360}\right)\right] d(\gamma) \\
& -\int_{2}^{90-t} F_{t} P_{t}\left[r_{p} \gamma\left(\frac{t}{360}\right)\right] d(\gamma) \\
& -\int_{0}^{360-t} \operatorname{SBIS}_{t}\left(\frac{T}{360}\right) d(\operatorname{SBIS})
\end{aligned}
$$

In general, this model is composed of two liquidity operations: (1) liquidity contraction and (2) liquidity expansion. The former has components of reserves requirement (v), liabilities to government (COg), payment of FLI and FPJP fees from the 
Ismal-Model of Islamic Monetary Operation for Liquidity Management in Islamic Banking

borrowing banks, and total outstanding of SBIS in the central bank. Meanwhile, the latter has components of currency in circulation (CR) and total islamic banking deposits (D). All of these variables become the candidate variables to be modelled in the next section of econometric modelling and interpretations.

\section{Econometric Model}

A dynamic (Autoregressive Distributed Lag - ARDL) model is employed to construct the model of islamic monetary operations (equation 10). ARDL is chosen due to the fact that a dependent variable is often influenced by the lag(s) of independent variable(s) and lag(s) of dependent variable itself (Studentmund 2005: 173-175). This ARDL model will examine what variables influence the islamic monetary operation. In addition, the interpretations of the model will inform us on the importance of such variables to be taken into account when the central bank conducts an islamic OMO.

The processes of econometric regression are: (1) defining the relevant variables for the model and model specification; (2) constructing the model including some tests to comply with the requirement of classical normal error terms and to make a robust Gauss-Markov model(BLUE); and(3) interpreting the results of the model.

\section{Definition of Variables and Model Specification}

All time series data in the model are using Bank Indonesia's islamic banking monthly data from December 2000 to February 2009. Because the islamic monetary operation is designed for short-term (weekly and/or daily) policy basis, the dynamic model is applicable to the short-term period as well. The islamic OMO per se operates under quantity target rather than price target since the bonus of SBIS does not exist to stimulate or attract the liquidity such as the one in conventional OMO. As such, the volume of SBIS (VIS) stands as a dependent variable and followed by independent variables referring to equation (10) described as follows:

1. Reserves requirement (v). This is one of the central bank considerations to determine how much target contraction/expansion of islamic OMO. Indeed, v functions side by side with SBIS.

2. Currency in circulation (CR). Undoubtedly, this variable lies as a macroeconomic concern of the conventional OMO as well as in the islamic one. If $\mathrm{CR}$ is high, both islamic and conventional OMOs, with a higher capability of liquidity contraction, have to reduce it.

3. The other variables, liabilities to government $(\mathrm{COg})$ and total islamic banks deposits $\left(\mathrm{D}_{\mathrm{t}}\right)$, are not included 
Gadjah Mada International Journal of Business, May-August 2009, Vol. 11, No. 2

Table 1. Statistical Summary (million Rp)

\begin{tabular}{lrrrrr}
\hline & Variable & & Mean & & Std. Deviation \\
\cline { 2 - 3 } \cline { 5 - 6 } Volume of SBIS (VIS) & $1,117,677$ & & 784,000 & & 940,561 \\
Currency in Circulation (CR) & 129,962 & & 119,956 & & 53,372 \\
Reserve Requirement (V) & 621,827 & & 544,895 & & 521,338 \\
\hline
\end{tabular}

in the model because these variables are fully controlled and anticipated by the central bank.

4. The lags of VIS. These lags of VIS represent the previous outstanding position of islamic OMO. The decision to absorb or release liquidity in islamic OMO entails both the previous (matured) volume of SBIS and the new excess liquidity stemming from the payment of SBIS fees.

The list of variables and their historical statistics are displayed in Table 1.

\section{Construction of Models}

\section{A. Stationary Test}

Before modelling, a unit root test is conducted to check the stationarity of variables. The basic idea of stationarity can be explained by taking a simple AR (Autoregressive) (1) process:

$$
\mathrm{Y}_{\mathrm{t}}=\mathrm{a}_{0}+\mathrm{a}_{1} \mathrm{Y}_{\mathrm{t}-1}+\varepsilon_{\mathrm{t}}
$$

where $Y_{t-1}$ is a lag of independent variable which might contain a constant and trend; $a$ is constant and; $\varepsilon$ is assumed to be white noise (Enders 1995: 70). If $\left|a_{1}\right| \geq 1$ and if $Y_{t}$ is a nonstationary series, that would mean that it has a trend, does not have constant mean, and has time variant of variance. The hypothesis of stationarity can be evaluated by testing whether the absolute value of $a_{1}$ is strictly less than one.

Two widely used tests in this area are Augmented Dickey-Fuller (ADF) and Phillips and Perron (PP). ADF reestimates equation (11) by subtracting $Y_{t-1}$ (Lutkepohl and Kratzig 2004: 54):

$$
\Delta \mathrm{Y}_{\mathrm{t}}=\alpha \mathrm{Y}_{\mathrm{t}-1}+\sum_{\mathrm{j}=1}^{\mathrm{p}-1} \alpha_{\mathrm{j}} \Delta \mathrm{Y}_{\mathrm{t}-\mathrm{j}}+\varepsilon_{\mathrm{t}} \ldots
$$

The process is integrated when $a$ (1) $=1-a(1)-\ldots-a_{p}=0$ where $\alpha=-\mathrm{a}(1)$ and $\mathrm{a}_{\mathrm{j}}{ }^{*}=-\left(\mathrm{a}_{\mathrm{j}+1}+\ldots+\mathrm{a}_{\mathrm{p}}\right)$. Null and alternative hypotheses are $\mathrm{H}_{0}: \alpha=0$ and $\mathrm{H}_{1}$ : $\alpha<0$; with $\mathrm{t}_{\alpha}<\alpha /(\operatorname{se}(\alpha))$. The basic idea of ADF is to correct high order serial correlation by adding lagged difference terms in the right hand side of the equation.

Meanwhile, Phillips and Perron (PP) use nonparametric statistical methods to handle the serial correlations in the error terms without adding lag difference terms (Gujarati 2004: 818). The results of stationary tests are depicted in Table 2. 
Ismal-Model of Islamic Monetary Operation for Liquidity Management in Islamic Banking

Table 2. Stationary Test

\begin{tabular}{|c|c|c|c|c|}
\hline \multirow{2}{*}{ Variable Name } & \multicolumn{2}{|c|}{ Augmented Dickey-Fuller } & \multicolumn{2}{|c|}{ Philip and Peron } \\
\hline & Level & $1^{\text {st }}$ Difference & Level & $1^{\text {st }}$ Difference \\
\hline VIS & -2.3568 & $-8.1176 * * *$ & -2.2182 & $-8.1714 * * *$ \\
\hline $\mathrm{V}$ & 4.6766 & $-8.1522 * * *$ & 5.8599 & $-8.1947 * * *$ \\
\hline CR & 5.4641 & -2.4414 & 0.1106 & $-16.2117 * * *$ \\
\hline
\end{tabular}

Table 2 reveals that all of the variables are not stationary in level but integrated in order one (first difference) with one per cent level of significance based on ADF and PP tests. Meanwhile, currency in circulation is not stationary in both levels and order one based on ADF test, but is found to be integrated in order one (first difference) with one per cent level of significance based on PP test. Therefore, these results indicate that the model in the subsequent section should integrate all variables in order one (first difference).

\section{B. Correlation and Causality Tests}

In order to assess the strength of the linear relationship between a dependent variable and independent variables and the direction of causality, correlation and Granger causality tests are used. The correlation coefficient formula is formatted as follows:

$$
\mathrm{r}_{1,2}=\frac{\sum\left[\left(\mathrm{X}_{1 i}-\overline{\mathrm{X}}_{1}\right)\left(\mathrm{X}_{2 i}-\overline{\mathrm{X}}_{2}\right)\right]}{\sqrt{\sum\left(\mathrm{X}_{1 i}-\overline{\mathrm{X}}_{1}\right)^{2} \sum\left(\mathrm{X}_{2 i}-\overline{\mathrm{X}}_{2}\right)^{2}}}
$$

with $r$ value ranges between $-1 \leq r \leq 1$. If two variables have a perfect positive linear correlation then $r=1$; if they have a perfect negative linear correlation then $r=-1$; and if there is no linear correlation then $r=0$. Basically, correlation coefficient detects the correlation of two variables without explaining the causality or direction of the correlation.

Meanwhile, the Granger causality specifically investigates how the dependent variable (Y) can be explained by its past values $\left(\mathrm{Y}_{\mathrm{t}-\mathrm{n}}\right)$ and lags value of independent variables $\left(\mathrm{X}_{\mathrm{t}-\mathrm{n}}\right)$. Mathematically, the Granger causality function is given as (Gujarati 2004: 697):

$$
\begin{aligned}
& Y_{t}=\sum_{i=1}^{n} \alpha X_{t-1}+\sum_{j=1}^{n} \beta_{j} Y_{t-j}+u_{1 t} \\
& \text { and } \\
& x_{t}=\sum_{i=1}^{n} \lambda X_{t-1}+\sum_{j=1}^{n} \delta_{j} Y_{t-j}+u_{2 t} \ldots \ldots \ldots . .
\end{aligned}
$$

$Y_{\mathrm{t}}$ is said to be Granger caused by $X_{\mathrm{t}}$ if $X_{t}$ and its lags explain $Y_{t}$, and vice versa. The outputs of correlation and Granger causality tests on all variables are shown in Tables 3 and 4. 
Gadjah Mada International Journal of Business, May-August 2009, Vol. 11, No. 2

Table 3. Coefficient of Correlation

\begin{tabular}{ccc}
\hline \multirow{2}{*}{ Variable Name } & \multicolumn{2}{c}{ Coeff. of Correlation } \\
\cline { 2 - 3 } VIS & \multicolumn{2}{c}{ CR } \\
\hline & 0.6796 & 0.6293 \\
\hline
\end{tabular}

Table 4. Granger Causality Test

\begin{tabular}{|c|c|c|c|}
\hline Null Hypothesis & F-Stat & P-Value & Conclusion \\
\hline V does not Granger Cause VIS & 5.9637 & 0.0164 & Not accepted \\
\hline CR does not Granger Cause VIS & 8.2903 & 0.0049 & Not accepted \\
\hline
\end{tabular}

The correlation test shows that the volume of SBIS (VIS) has more than 50 per cent indication of a perfect positive linear correlation with currency in circulation (CR) and reserves requirement $(\mathrm{V})$ (Table 3$)$. VIS and CR denote a coefficient of correlation value of 0.63 while VIS and V records a value of 0.68 , which is stronger than the former. Referring to this test, the three variables have strong correlations among each other compared to the other candidate variables in equation (10).

Further investigation with Granger causality test enhances the output of correlation test. As shown in Table 4, the Granger causality test suggests that reserves requirement $(\mathrm{V})$ and currency in circulation (CR) indeed Granger cause the volume of SBIS (VIS), and not the other way around. Moreover, the lags of VIS also explain the current value of VIS. This finding confirms that the decision to treat VIS as a dependent variable is very reasonable.

\section{Results of Regression}

The estimated model of the islamic monetary operation for liquidity management is displayed in Table 5. The regression has fitted the requirement of classical normal error terms such as autocorrelation, hetero-scedasticity, and multicolinearity tests including Ramsey reset test for the correctly specified equation. Moreover, the coefficients of individual and overall variables are robust to Gauss-Markov requirement of best (minimum variance), linear, unbiased estimator (BLUE). Hence, the complete econometric model of islamic monetary operation is formulated as:

$$
\begin{aligned}
\Delta\left(\mathrm{VIS}_{\mathrm{t}}\right)= & \mathrm{c}+\beta_{1} \Delta(\mathrm{V})-\beta_{2} \Delta\left(\mathrm{V}_{\mathrm{t}-2}\right) \\
& +\beta_{3} \Delta\left(\mathrm{CR}_{\mathrm{t}-2}\right)+\beta_{4} \Delta\left(\mathrm{CR}_{\mathrm{t}-11}\right) \\
& -\beta_{5} \Delta\left(\mathrm{VIS}_{\mathrm{t}-5}\right)+\mathrm{e} \ldots \ldots . . .(15)
\end{aligned}
$$

The estimated model reveals that the marginal volume of SBIS ( $\Delta$ VIS $)_{t}$, which is the target allotment of OMO 
Ismal-Model of Islamic Monetary Operation for Liquidity Management in Islamic Banking

auction, is influenced by the marginal positions of current reserves requirement $\left(\Delta \mathrm{V}_{\mathrm{t}}\right)$, lag-two period of reserves requirement $\left(\Delta \mathrm{V}_{\mathrm{t}-2}\right)$, lag-two period of currency in circulation $\left(\Delta \mathrm{CR}_{\mathrm{t}-2}\right)$, lageleven period of currency in circulation $\left(\Delta \mathrm{CR}_{\mathrm{t}-11}\right)$, and prior five periods of marginal volumes of SBIS $\left(\Delta \mathrm{VIS}_{\mathrm{t}-5}\right)$.

As discussed above, in managing liquidity with SBIS instrument in islamic OMO, the target volume of SBIS should take into account the position of reserves requirement because both of them function as the islamic monetary instruments to maintain the adequacy of liquidity in the industry.
As such, the significant position of reserves requirement in the estimated model is reasonable and reliable. Further, the current marginal position of reserves requirement in the model disposes the current position of liquidity in the islamic banking industry while their lags notify the quarterly patterns of the liquidity.

On the other hand, the position of currency in circulation is definitely one of the ultimate targets of liquidity contraction/expansion via islamic OMO. The estimated model approves this point. However, in order to influence the position of currency in circu-

Table 5. Estimated Model of Central Bank Liquidity Management

\begin{tabular}{lrc}
\hline \multicolumn{2}{c}{ Dependent Variable: D(VIS) } \\
\hline Independent Variable & Coefficient & t-Stat. \\
\cline { 2 - 2 } Constant & 137137 & -2.7279 \\
D(V) & 10.6930 & 8.2409 \\
D(V(-2)) & -2.5244 & -1.8793 \\
D(CR(-2)) & 10.0915 & 3.1880 \\
D(CR(-11)) & -10.6927 & -2.8746 \\
D(VIS(-5)) & -0.2593 & -3.1539 \\
& & \\
\hline Diagnostic Analysis & Value & P-Value \\
R-squared & 0.5712 & \\
Residual Sum of Square & $8.35 E+12$ & \\
Akaike Info Criterion & 28.2633 & \\
F-Statistics & 21.5815 & 0.0000 \\
Jarque Bera & 0.6779 & 0.7125 \\
LM Test & 2.1910 & 0.1427 \\
ARCH LM test & 0.8533 & 0.3582 \\
Ramsey RESET & 0.3933 & 0.5323 \\
\hline
\end{tabular}


lation, islamic OMO has to remember the pattern of currency in circulation in the economy. Meanwhile, the position of SBIS volume, another output of the model, helps the central bank determine how much liquidity contraction/expansion is to be decided in the islamic OMO.

\section{Interpretations of the Model and Suggestions}

The interpretations of the regression connote some important messages with respect to islamic monetary operation for liquidity management in islamic banking industry. First of all, the current marginal volume of SBIS depends on both the current marginal position and the last two periods of the reserves requirements. As the partner of SBIS in the islamic monetary operation, the model suggests the central bank to consider such reserves requirement periods when auctioning SBIS in islamic OMO. In the case of persistent adjustment to the liquidity position, reserves requirement is the best option to be used as it is fixed, permanent, and stipulated by the central bank. However, in the case of temporary adjustment to the liquidity position, auction of SBIS in islamic OMO is the most suitable option.

Secondly, the volume of SBIS also relies on the marginal of the last two and eleven periods of currency in circulation. These two kinds of periods of currency in circulation precisely represent two of the three general or normal patterns of currency in circula- tion: (1) quarterly pattern and (2) annual pattern. The former indicates the quarterly business cycle while the latter shows the annual trend of the business cycle. The two patterns benefit the monetary authority by informing on how much liquidity is going to be absorbed or released in the industry.

Finally, the marginal position of the last five periods of the volume of SBIS determines the decision on the current marginal volume of SBIS. This represents another pattern of currency, which is the semiannual pattern. The islamic OMO should take into account this pattern since these prior five periods disclose information on: (1) the last outstanding volume of SBIS in the central bank account; (2) the matured volume of SBIS; and (3) the total amount of SBIS fees paid to depositors. Indeed, referring to these previous five periods of SBIS volume is very important when OMO auction is about to be arranged.

In the end, the overall interpretations of the model leave one definitive finding, which is the application of islamic monetary operation with SBIS instrument through OMO still follows the style of conventional OMO. The conventional OMO with interest based monetary instrument (SBI) is arranged by the central bank to manage and control the adequacy of liquidity (absorbing excess liquidity or injecting liquidity) per se, as mentioned in the earlier section. Nonetheless, the application of islamic monetary instrument through islamic OMO should go beyond such conventional purposes as 
Ismal-Model of Islamic Monetary Operation for Liquidity Management in Islamic Banking

said by Chapra. Besides managing and controlling the adequacy of liquidity in islamic banking industry, the islamic monetary operation is arranged to assist the islamic banks to utilize liquidity of the industry and develop the economy (Chapra 1985: 10-30).

For instance, the islamic monetary instrument is an alternative for islamic banks to invest funds in the real sectors. In the case of surplus liquidity in the industry, islamic monetary instrument should not only contract the liquidity but also relocate it to real projects in the real sectors. Hence, in sharia perspective, such islamic monetary instrument can be implemented within the investment contract such as Mudarabah or Musharakah instead of Wadiah (the underlying contract of $\mathrm{SWBI}^{8}$ ) or Joalah (the underlying contract of SBIS).

In practice, SBIS has been used mostly for the placement of surplus funds without extending them to finance the real sectors. Therefore the three variables in the islamic model that influence the islamic monetary operation are also variables considered in the conventional monetary operation (Agung et al. 2001: 10-25). To some extent, this condition is understandable because:

1. The monetary operation in the country is still mostly based on the conventional mechanism (interest based OMO with Bank Indonesia’s
Certificate or SBI) because almost all of the liquidity belong to the conventional banks. Therefore, the monetary policy stance (tight or loose monetary policy) in the conventional OMObecomes the stance of SBIS auction in islamic OMO as well. The deterministic factors in the conventional auction are valid in the islamic auction too.

2. The market share of islamic banking industry is trivial and the islamic banks have been successfully functioning as financial intermediaries to utilize the public funds to invest in the real sectors (Ismal 2009: 210). Hence, the islamic monetary operation has not significantly worked as liquidity balancer yet.

3. The service fees (Joalah) of SBIS follow the rate of SBI, which is an interest-based monetary instrument. It means that the operation of SBIS as islamic monetary instrument is not fully independent and reflects the real islamic monetary function to relocate the funds from the financial sector to the real sector.

However, in the near future, the function of islamic monetary operation should be redirected and reoptimized to the ideal applications as being suggested by moslem scholars above. This can be realized by varying the contract of islamic monetary instruments, from just Joalah and

\footnotetext{
${ }^{8}$ SWBI is the Bank Indonesia Wadiah Certificate, the prior islamic monetary instrument used by Bank Indonesia.
} 
Gadjah Mada International Journal of Business, May-August 2009, Vol. 11, No. 2

Wadiah which do not give direct impacts to the real sectors into Mudarabah or Musharakah which directly release the funds to the real sectors. As such, the central bank is suggested to issue the islamic investment monetary instruments besides the existing islamic monetary instruments.

By issuing these new islamic monetary contracts, the central bank can engage in the real economic activities and works more than just managing the supply and demand for liquidity in the industry. This is basically the true purpose of the islamic monetary operation. Subsequently, the deterministic variables of the islamic OMO will also involve real sector variables such as Gross Domestic Product (GDP) or production index, profit sharing of the entrepreneurs, domestic and external trade activities, besides the financial sector variables.

\section{Closing Remarks}

The conventional central bank model of monetary operations for liquidity management gives the idea of what variables are involved in the monetary operation model, and contributes to the modelling of islamic monetary operation model for islamic banking industry. Such islamic model suggests that variables of reserves requirement, currency in circulation, and outstanding volume of SBIS cooperatively influence the islamic monetary operation with SBIS instrument. However, the most important finding is that the application of islamic OMO still follows the style of conventional OMO for several reasons. The paper suggests the application of investmentbased islamic monetary instruments to implement the ideal purposes of islamic monetary operation.

\section{References}

Agung, J., R. Morena., B. Pramono, and N. J. Prastowo. 2001. Bank lending channel of monetary transmission in Indonesia. Working Paper of Directorate of Economic Research and Monetary Policy. Bank Indonesia, Jakarta.

Ahmed , Z., M. Iqbal, and M. F. Khan. 1983. Money and Banking in Islam. International Centre for Research in Islamic Economics, King Abdul Aziz, Jedah, and Institute of Policy Studies, Islamabad.

Bindseil, U. 2000. Central Bank Liquidity Management: Theory and Euro Practice. European Central Bank Publication.

Bank Indonesia. 2005. Bank Indonesia Regulation Number 7/24/PBI/2005 Concerning Intraday Liquidity Facility for Commercial Bank Based on Sharia Principles. Bank Indonesia, Jakarta, Indonesia.

Bank Indonesia. 2005. Bank Indonesia Regulation Number 7/23/PBI/2005 Concerning The Short Term Financing Facility for Sharia Banks. Bank Indonesia, Jakarta, Indonesia. 
Ismal-Model of Islamic Monetary Operation for Liquidity Management in Islamic Banking

Bank Indonesia. 2006. Bank Indonesia Regulation Number 6/21/PBI/2006 Concerning Reserve Requirement for Sharia Banks. Bank Indonesia, Jakarta, Indonesia.

Chapra, U. 1985. Towards a Just Monetary System. Islamic Foundation, Leicester.

Enders, W. 1995. Applied Econometric Time Series ( $1^{\text {st }}$ ed.). Canada: John Wiley \& Son: 70.

Freixas, X., and J-C. Rochet. 1999. Microeconomics of Banking ( $3^{\text {rd }}$ printing). London, England: The MIT Press.

Gujarati, D. 2004. Basic Econometrics (4 ${ }^{\text {th }}$ ed.). USA: The McGraw-Hill Companies.

Ismal, R. 2009. Industrial analysis of liquidity risk management in Islamic banking. Journal of Islamic Banking and Finance 26 (2). Karachi: International Association of Islamic Banks.

Lutkepohl, H., and M. Kratzig. 2004. Applied Time Series Econometrics. Cambridge University Press.

Mills, D. C, Jr. 2005. Alternative central bank credit policies for liquidity provision in a model of payments. Finance and Economics Discussion Series. Division of Research and Statistics and Monetary Affairs, Federal Reserve Board, Washington DC.

Studenmund A. H. 2005. Using Econometrics: A Practical Guide. Addison-Wesley Series in Economics ( $5^{\text {th }}$ ed.). United Kingdom: Person Higher Education Inc.

Walsh, C. 2003. Monetary Theory and Policy. The MIT Press, Cambridge, Massachusetts, and London. 